\title{
Conduct of conduits: Engineering, desire and government through the enclosure and exposure of urban water
}

DOI:

$10.1111 / 1468-2427.12524$

\section{Document Version}

Accepted author manuscript

Link to publication record in Manchester Research Explorer

\section{Citation for published version (APA):}

Usher, M. (2018). Conduct of conduits: Engineering, desire and government through the enclosure and exposure of urban water. International Journal of Urban and Regional Research, 42(2), 315-333.

https://doi.org/10.1111/1468-2427.12524

\section{Published in:}

International Journal of Urban and Regional Research

\section{Citing this paper}

Please note that where the full-text provided on Manchester Research Explorer is the Author Accepted Manuscript or Proof version this may differ from the final Published version. If citing, it is advised that you check and use the publisher's definitive version.

\section{General rights}

Copyright and moral rights for the publications made accessible in the Research Explorer are retained by the authors and/or other copyright owners and it is a condition of accessing publications that users recognise and abide by the legal requirements associated with these rights.

\section{Takedown policy}

If you believe that this document breaches copyright please refer to the University of Manchester's Takedown Procedures [http://man.ac.uk/04Y6Bo] or contact uml.scholarlycommunications@manchester.ac.uk providing relevant details, so we can investigate your claim.

\section{OPEN ACCESS}




\section{Conduct of conduits: Engineering, desire and government through the enclosure and exposure of urban water in Singapore}

Mark Usher, University of Manchester

This article scrutinizes the relationship between governmental reform and infrastructural change in Singapore. Focusing on the role of engineers, it is argued that neoliberal decentralization has occurred through the physical reconfiguration of drainage. Neoliberalization is conceived as a localized technical response to a public health crisis resulting from infrastructural enclosure, which is orchestrated on and through the materialecological environment. A closed drainage system consisting of trapezoidal canals and concrete culverts had produced an ideal breeding environment for dengue-carrying mosquitoes, undermining the state's centralized approach to water governance. This article reorients Michel Foucault's analytics of government around engineering and the 'milieu' to consider how drainage infrastructure was consequently opened up to an emerging civil society to relieve pressure on the state and allow greater public participation in the surveillance and management of canals, pipes and culverts. Alongside landscape architects, engineers would increasingly turn to naturalized waterways and open catchment policy to encourage citizens to form an affective bond with water and to inculcate principles of individual ownership and responsibility through physical contact. The article contends that with the proliferation of integrated resource management systems, governmental power is increasingly exercised through the liveliness as well as the fetishization of urban infrastructure.

We are in a generalized crisis in relation to all the environments of enclosure Deleuze, 1992, p.3-4

\section{Introduction}

The everyday infrastructural workings of the state have become a 'matter of concern' (Barry 2013) not only for civil engineers but increasingly for scholars in the humanities and social sciences. These scholars argue that canals, roads, railways, dams, utilities and telecommunications systems provide a networked technological medium through which 
administrative control over territory has been centralized (Worster, 1985; Mukerji, 2009; Collier, 2011; Guldi, 2012; Swyngedouw, 2015), leading, in many cases literally, to the 'concretization of state power' (Harvey, 2010: 33). Indeed, the material properties of concrete, which make it plastic before setting and durable after, waterproof and fireproof, uniform in colour and consistency, inexpensive and amenable to mechanized construction, are ideally suited to territorial expansion and nation-building (Forty, 2012). Engineers and architects can rearrange urban space and lastingly reconfigure relations between humans and their material surroundings in the interests of centralized government, sculpting marionette strings for the conduct of conduct cast in concrete (Minuchin, 2013). The enchanting allure of concrete, which promises connectivity, durability and unprecedented verticality, therefore continues to fuel the developmental ambitions of engineers operating in rapidly urbanizing countries, alongside the states that employ them (Harvey and Knox, 2012; Harris, 2013).

Focusing on drainage and hydraulic engineering, this paper will examine how reinforced concrete was initially used in Singapore to centralize administrative control over territory, the population and water. However, departing from the narrative above, this precipitated a series of interrelated crises resulting from closed technological systems, culminating in recurrent outbreaks of dengue which directly undermined the authority and governmental capacity of the centralized state. Once the empirical context of Singapore has been outlined, Michel Foucault's analytics of government will be reoriented around his original concern with urban infrastructure and engineering. The paper will subsequently turn to the specific case of drainage, which considers how engineers have technically facilitated a process of neoliberal decentralization through physical interventions into the urban fabric, opening up formerly concretized canals to an emerging civil society (although, see Hillier, this issue). Legislation was introduced in 1975 that provided a legal basis for the technological centralization of water, executed through extensive canalization and reservoir construction. In response to the crisis, statutory changes were made in the early twenty-first century that decentralized public ownership rights, facilitating the transition to a networked form of government that affectively calibrates citizens' relationship with water through volunteerism and physical contact.

To collect the necessary data, an archival analysis was undertaken during a fieldwork period of approximately 18 months. Annual reports, specification booklets, conference proceedings and specialist publications from various professional bodies were analyzed. A process of archival triangulation was conducted by examining annual reports from state departments in respect to newspaper archives (1831-2009) and Parliamentary records 
(1955-2014). These textual sources have been supplemented with interview data in order to obtain personal insights. The sample consists of high- and middle-ranking civil servants $(n=8)$, industry figures $(n=5)$, third sector employees and volunteers $(n=8)$, and professionals $(n=6)$ who have been directly involved in construction and planning processes.

\section{Grounding government}

On gaining independence as an autonomous sovereign island in 1965, ejected from the Federation of Malaysia and its common market due to a breakdown in diplomatic relations, the incumbent People's Action Party (PAP) was charged with overcoming the associated constraints of geographical and political isolation through centralized planning and social control measures. 'Founding Father' and Prime Minister of Singapore from 1959 to 1990, Lee Kuan Yew inculcated an appreciation of hierarchy and meritocracy within the political establishment and wider society, championing the value of discipline, work and corporeal punishment (Mauzy and Milne, 2002).

State-led economic growth has since been explicitly correlated to the continued existence of the island as a viable and autonomous political entity. Legislation and electoral rules have been periodically adapted and political opposition effectively suppressed through surveillance, sanctions and media interventions, which has ensured the continued incumbency of the PAP in a parliamentary system. The labour force was forcefully pacified through a range of disciplinary measures, including changes in industrial legislation, productivity drives and provision of public housing, which fragmented ethnic enclaves, reduced wage demands, facilitated conscription and bound citizens to a system of mortgage debt (Chua, 2011). Land acquisition policy was also amended in 1966 enabling the enforced procurement of private property, bringing approximately $85 \%$ of territory under state control (Shatkin, 2014). Similarly, environmental initiatives such as tree-planting and park construction have been centrally administered to create a habitat attractive to international business and mobile professionals, under the so-called 'clean and green' model (Neo, 2007).

However, from the 1990s onwards a coordinated programme of liberalization would be implemented through the notion of 'active citizenship', which sought to selectively decentralize responsibility to an emerging civil society and private sector by encouraging entrepreneurialism, participation and personal autonomy (Yeung, 2000). The PAP officially acknowledged that its formerly disciplinary, top-down approach to government would be inappropriate for a service-based workforce in a digital, creative economy, which would stifle individual initiative, jeopardize the reputation of Singapore as a 'global city' and increase the 
likelihood of public resistance. Whereas previously self-restraint and docility were encouraged, the population would henceforth be governed through aspirational notions of freedom, lifestyle and 'liveability' (Teo, 2014). There is now greater public willingness to contest government policy, due in part to the rise of social media. Furthermore, the growing credibility of the Worker's Party, which won the most opposition seats ever in the 2011 general election, has profoundly transformed the political climate.

Although this political and administrative unfurling has been examined in previous studies, the process of neoliberalization has generally been perceived as a shift in policy objectives, incorporating 'best practices' from a western context (Haque, 2004; Pow, 2014). This emphasis on neoliberalism as a mobile rationality that redefines institutional landscapes is discernible in the wider critical literature (Brenner et al, 2010). This paper will demonstrate that neoliberal restructuring can be interpreted more broadly as a localized technical response that is endogenous to governmental regimes. Here, a closed drainage system precipitated a public health crisis arising from mosquitoes breeding in concrete culverts, which produced and concealed instances of water pooling. This destabilized the formerly hierarchical approach to government that functioned through the centralization and monopoly control of water resources, prompting a programme of infrastructural modification and governmental reform. This confirms what Mitchell (2002) observed in colonial Egypt, where mosquitos and water possessed an active if inadvertent agency to interrupt, reorganize and modify the techno-political formation of the state and its capacity to govern.

As will be reiterated in the following section, government according to Foucault was necessarily exercised in respect to the material environment, applied not only to an institutional but physical landscape formed of tangled shrubs and technological networks, soil, swamp and meandering waterways (Foucault, 2007). Drainage is not merely reflective of this shift in governmental strategy but actively and physically constitutive, providing a technological medium through which the population is orchestrated more effectively in accordance to shifting norms, desires and subjectivities (Gandy, 2014). Conventionally portrayed as technocratic and apolitical, engineers have been integrally involved in this process of governmental reform, demonstrating that socio-economic restructuring is not necessarily epochal, structural and inexorable, but technical, contingent and adapted to the material specificities of place (Ong, 2007; Collier, 2011). By retrofitting concrete canals and drains under revised urban planning and design guidelines, engineers assisted in physically reconfiguring the administrative boundary between the state and the population, thereby technologically unbundling a neoliberal form of government. This paper corroborates that 
the mundane details of engineering should therefore be taken more seriously by scholars of urban governance and politics (Björkman, 2015).

\section{Governmentality, infrastructure and the 'mechanical arts'}

According to Foucault, to govern is to arbitrate between human inhabitants and their physical environment, and thereby mediate and naturalize complex coexistences of citizens and circulations. Certainly, an important aspect of this would be the 'thick natural phenomenon' (Foucault, 2007: 71) of population, or the biopolitical relationship between the state and human bodies, which has received a great deal of attention from scholars. However, this constitutes just one of three key correlates of government, the remaining two being the milieu, the physical environment constituted of human and nonhuman elements, and circulation (Foucault, 2007: 63-66). When the latter correlates are taken into serious consideration, which has not always or even regularly been the case, then we can do justice to Foucault's (2007: 23) original assertion that if the sovereign 'wants to change the human species...it will be by acting on the milieu'.

More recently, presumably as a consequence of the material turn in the humanities and social sciences, there have been isolated attempts to re-establish the analytical linkages that Foucault identified between population, circulation and the milieu (Joyce 2003; Collier, 2011; Elden, 2013; O'Grady, 2013; Gabrys, 2014; Usher, 2014; Lemke, 2015; Sage et al, 2015). And whilst occasionally understating Foucault's original emphasis on public infrastructure, some critical scholars have shifted attention to urban resource flows in the provisioning of populations (Bridge, 2013; Wakefield and Braun, 2014; Collier and Lakoff, 2015). Most relevant to the arguments here, urban water was indeed integral to Foucault's concerns and investigations into government, which he returned to frequently; 'coexistences...between men and things, the question of water, sewage, ventilation' (Foucault, 1980: 150, emphasis added).

As Foucault (1989a: 336) made clear, the art of government was not merely applied to the issue of urbanism but emerged precisely through the expansion of architecture and infrastructure in European cities during the seventeenth and eighteenth centuries, providing 'the matrix for the regulations that apply to a whole state'. The city would provide the template for territorial expansion, directly implicating the ordinary specialists of hygiene, infrastructure and logistics in the consolidation of modern state power and 'urbanization of the territory' (Foucault, 2007: 336). Therefore, it is not altogether surprising that Foucault harboured a longstanding interest in architectural design, but his related concern with 
engineering and the 'mechanical arts' (Ibid: 335) has been left relatively underexplored. And indeed, Foucault argued that engineers more than architects were the central figures in the development of modern forms of governmentality, the 'builders of bridges, roads, viaducts, railways...the engineers of the three great variables - territory, communication, and speed' (Foucault, 1989a: 339).

Since the early 1970s, Foucault had been collaboratively contemplating the normalizing role of civil engineers, urban infrastructure and public amenities alongside Gilles Deleuze, Felix Guattari and others (Elden, 2016). The collaborative projects that Foucault contributed towards, particularly the Centre d'Études, de Recherche et de Formation Institutionnelle (CERFI), examined how vital infrastructures of urban life- hospitals, schools, transport networks, utilities, parks and housing- technologically extended the reach of the modern state into the private sphere through public services and expertise. The group interpreted infrastructure as the collective unconscious of the city, constituting a type of affective circuitry, which provide machines for the production of subjectivity and channelling of desire (Brott, 2012). Although this material is largely unpublished in English, a series of reports were produced under the working title of 'Equipments of Power', which examined how urban habitats are formed, sustained and regulated in an everyday register through the infrastructural management of circulation and the distribution of public goods (Elden, 2016).

In one particularly informative exchange from 1973, Foucault (1989b: 106) takes the 'collective equipment' [public infrastructure] of the roadway as a case study, which he considered to be 'one of the elements of crystallization of state power' (see Harris, this issue). Again, by shaping collective existence, the 'engineer from Public Works' is involved in the co-production of infrastructure and government, acting as an 'agent and subject of normality' under the authority of the 'industrial State' (Ibid: 107). Ten years later Foucault (1989a) would deliberate the development of the railway, hinting towards the demographic, geopolitical and behavioural impacts of this feat of modern engineering [1]. And certainly, this collaborative work on the collectivizing capacity of civil engineering was central to Foucault's original theorization of governmentality (Usher, 2014).

There is now widespread acknowledgement that infrastructural networks and material flows are formative of the modern state and modes of government (McFarlane and Rutherford, 2008; Bennett and Joyce, 2010), where territorial jurisdictions and political collectivities have been physically engineered into existence (Barry, 2001; Joyce, 2013; Mukerji, 2009; Pritchard, 2011; Carroll, 2012; Guldi, 2012; Harvey and Knox, 2012; Camprubí, 2014; Swyngedouw, 2015). According to this perspective, the state assumes concrete, tangible form and ontological solidity as technological networks emerge, 
consolidate and integrate, eventually becoming interlocked systems of naturalized practices and processes. Engineering as technology, practice and expertise is therefore integral to modern state formation, enhancing its territorial connectivity and political legitimacy (Mukerji, 2003).

Of particular interest to Foucault, and also to the concerns of this paper, was the shift from discipline to security, centralized to decentralized regulation. In contrast to discipline, security does not attempt to contain and control through hierarchical interventions but intends to adapt to the autonomy and reality of socio-ecological processes by identifying, optimizing and harnessing the discernible proclivities of nature. Foucault (2007: 73) suggests that to govern is to stimulate and manipulate the 'naturalness of desire', which provides a potent basis for state aggrandizement through the 'passional economy' (Miller and Rose, 2008: 141) of human urges and instincts. Neoliberalism, the 'other face' (Foucault, 2008: 65) of security, operates on the premise of limitation, through a reflexive and continuous critique of its own methods of government.

In the contemporary neoliberal period, centralized regulation has been supplanted by a more dispersive, relational mode of government that is premised not on the mastery of nature and water but recognition of its inextricable connectedness to human processes (Linton and Budds, 2014). This follows a previous era of water governance characterized by top-down, techno-scientific control under a centralized state, which Kaika (2005: 6) refers to as the 'heroic moment of modernity's Promethean project', lasting from the late nineteenthcentury to late twentieth-century. The 'modern infrastructural ideal' prevailed during this period, predominantly in Western, developed countries, which prescribed universal, monopolistic provision and coordination of resources through centrally administered technological networks (Graham and Marvin, 2001).

State engineers, depicted as the 'modern Prometheus' (Kaika, 2006: 276) and endowed with immense authority and prestige by public water boards, were employed to construct large-scale hydraulic infrastructure that sought to contain and channel water in fixed, predetermined conduits, invariably located underground (Gandy, 2002). This produced the effect that nature was in fact external to the city and its inhabitants, concealing and 'silencing' water, rendering 'occult the social relations and power mechanisms that are scripted in and enacted through these flows' (Kaika and Swyngedouw, 2000: 121). And certainly, this process of 'blackboxing' flows through infrastructural enclosure has been an overriding concern of urban political ecology (Graham and Thrift, 2007).

However, during the late twentieth century, fiscal, accumulation and environmental pressures began to undermine the hierarchical 'Fordist' approach to water management, 
alongside the emergence of neoliberal doctrine (Swyngedouw, 2004; Bakker, 2010). In the case of drainage, the fall of Prometheus would play out in reoccurring scenes of decreasing water quality due to end-of-pipe, rapid conveyance methods, deteriorating ecological systems and flash floods resulting from impervious urban materials. From the 1960s onwards, integrated water resources management (IWRM) began to materialize based on an alternative scripting of nature, employing techniques of source control (e.g. bioswales, wetlands, green, permeable surfaces) to incorporate the water cycle into urban areas (Karvonen, 2011; Waley and Åberg, 2011). The modern hardware of drainage infrastructure, forming what Jones and Macdonald (2007: 536) have termed a 'piped prison' of enclosed concrete culverts and trapezoidal canals, has been complemented by 'soft' planning and design measures, involving landscape architects, ecologists, and where possible, affected communities, as well as state engineers. Yet, whereas the geographical characteristics of modernist approaches to water infrastructure have been closely scrutinized (Kaika, 2005), the spatial signature of neoliberalism is understudied (Monstadt, 2009). With the contemporary shift to integrated, user-oriented resource management systems, power is increasingly exercised through the transparency rather than fetishization of metabolic flows as conventionally understood in critical urban studies, inaugurating alternative forms of governmentality premised on the 'liveliness' of infrastructural networks (Amin, 2014).

\section{Drainage engineering and neoliberal decentralization in Singapore}

\section{Administrative centralization via the canalization of water}

Since the 1960s, local catchment has been progressively expanded into urban areas of Singapore to augment imported water from Malaysia and protected reservoirs in the Central Water Catchment Area (CWCA). Amounting to just $11 \%$ in 1965, catchment area now constitutes two-thirds of Singapore's limited land surface, which divert rainwater into seventeen reservoirs as part of a separate sewerage and stormwater system. When reservoirs are at full capacity, stormwater is conveyed to the sea. Moreover, with the departure of the British colonial administration, the pipeline connecting Singapore with Malaysia had become significantly more vulnerable, particularly during prolonged episodes of geopolitical posturing. In this quite genuine but strategically augmented environment of emergency, the PAP adopted an interventionist, developmental approach to statecraft legitimated by frequent allusion to the chronic vulnerability of Singapore. A series of plans were implemented that sought to accelerate a process of national industrialization through infrastructural development and inward investment. 
Integral to the Development Plan of 1961 was the comprehensive roll-out of drainage infrastructure across the entire territory of Singapore to provide for incoming manufacturing firms and a growing population, with $\mathrm{S} \$ 12$ million ring-fenced for expansion (Hansard, 1961). The Public Works Department had warned some ten years earlier that Singapore was facing an 'enormous drainage problem' resulting from the 'alarming soil erosion' of earthen banks of conveyance canals, exacerbated by a labour shortage and lack of engineering expertise (ST, 1951). Under the direction of Chief Drainage Engineer Mr F Pelton, hastily flown in from Kuala Lumpur on an emergency basis, widespread canalization under a centralized drainage authority was planned for Singapore, 'to get the water right off the land and into the sea, or else...to retain it in a properly planned and constructed reservoir' (Hansard, 1958). The status of engineers would escalate over the ensuing decades as the administration of water was increasingly centralized under the techno-political ambit of the state, exemplified by the containment of hydrological flows in secured concrete conduits.

Sir Bruce White, Wolfe Barry and Partners, a British engineering consultancy firm, had previously suggested that shifting to internal sources of water collection located outside of the CWCA would inevitably involve higher levels of environmental control, in addition to canalization, to minimise purification costs (White et al, 1950: 11). Lee Kuan Yew corroborated this during a speech in 1971 , instructing that at least $25 \%$ of a daily average rainfall of 700 million gallons must be collected in reservoirs for water supply, as well as flood control, by 1980, necessitating the immediate and categorical capture of run-off (NAS, 2012a: 407). Released one year later, the Water Master Plan placed added emphasis on achieving self-sufficiency from Malaysia through expanding local catchment area from $11 \%$ to $75 \%$. As catchment and urban areas increasingly overlapped due to the dual shortage of land and potable water, general anti-pollution measures became explicitly linked to water quality and thereby legitimized the stringency of the former.

In 1975, the 'Water Pollution Control and Drainage Act' (WPCDA) provided the necessary 'teeth' for more effective catchment management. Mr Barker, then Minister for Law and the Environment, pitched the Bill to Parliament as a matter of urgency where he declared that existing water pollution laws were 'inadequate and somewhat obsolete' (Hansard, 1975). Henceforth, water could not be legally extracted from anywhere on the island without permission from the water authority, the Public Utilities Board (PUB), as public standpipes decreased from 218 in 1971 to just 2 in 1975. In regard to catchments, environmental control over farms, food suppliers, boatyards, households and other activities was extended in the interests of claiming run-off water for drinking purposes, necessitating 
a large-scale clearance and resettlement programme. This was spearheaded by one of Singapore's most influential civil servants and long-serving engineers, Lee Ek Tieng, then acting as Permanent Secretary of the Ministry of the Environment. Whether managing sanitation and drainage schemes as he did in his early career, or overseeing the operations of international financial institutions as was subsequently the case, Lee tended to downplay the political resonances of his projects.

According to Tan Gee Paw, who would later serve as PUB chairman, the Master Plan for cleaning up the central rivers emphasised that 'it would cause a lot of social disruption, the social cost would be very high', however, they would concentrate on purely engineering issues, thereby avoiding 'the social, political part, that has to be managed by politicians' (NAS, 2007: 65). Corroborating this exercise in depoliticization, Tan Teng Huat, Chief Engineer of Pollution Control, proposed the most effective method for public relations was to emphasise the greater good for the nation, such as the creation of water resources for future generations (ENV, 1990). The strategic efficacy of engineers for technically implementing manifestly political programmes of government was officially recognised by their career advancement to high-end civic positions. Exalted and amply remunerated, this emerging cohort of civil technicians was effectively constructing a modern territorial state through the coordinated expansion of drainage infrastructure.

The WPCDA, alongside the Drainage Master Plan introduced the same year to accelerate canalization, also streamlined construction protocols and provided strong legislative support for private land acquisition and the enhanced protection of drainage infrastructure as it penetrated and connected territorial space (ENV, 1975). Drainage projects were prioritized over private land on the basis that 'a free flow of water' is 'essential' for national development and security (Hansard, 1975). If it was deemed in the interests of the state, private drains could be appropriated or owners may be ordered to improve a drain without compensation for loss of land. The erection of structures over drains would be restricted or subsequently dismantled by state officials to protect what was considered to be a nationally sensitive circulation. Under the Ministry of the Environment, the canalization and administrative centralization of water would occur in tandem and be durably cast in concrete, predicated on flood alleviation and the protection of water resources for domestic consumption. Drainage construction increased by $50 \%$ on the previous year and included the first major subterranean projects, redirecting water circulation underground (ENV, 1972).

This was the outcome of a hydrological report which advocated the replacement of an open drainage system with a closed network as it would contain and protect water more effectively (NAS, 1970). The canalization programme would come to resemble a coordinated 
military campaign, executed by a taskforce of engineers working at the behest of the state. According to Tan Gee Paw, an obvious student of the Pelton school of thought, 'the battle cry in those days was build the canals, send the water out to sea, relieve the flooding' (NAS, 2007: 57). Even with an extensive drainage infrastructure in place to augment supply and alleviate flooding, the Head of the Drainage Department admitted 'it was a difficult time...the bulldozers were bulldozing down the rural areas, people were being re-sited' (Ibid: 56).

Trapezoidal canals and culverts spread through suburban settlements, capturing and incarcerating rainwater, separating it from adjacent areas in a concrete prophylactic, which would then be rapidly conveyed with mechanical efficiency to heavily secured reservoirs or the sea. This was rationalized by an imaginary of emergency, which concerned the 'strategic importance of water' under the 'vagaries of nature and the whims and fancies of man [sic]' (Hansard, 1971). A closed network of canals, drains and culverts formed a centripetal, disciplinary system of containment, which regularized the rhythm and route of water through standardized design specifications and 'functional separation' from disparate or dangerous circulations (Scott, 1998). Disciplined circulation has its route and rhythm established in accordance to definitively fixed parameters, where here the velocity of water flow should always be limited to a minimum of $1 \mathrm{~m} / \mathrm{sec}$ and maximum of $3 \mathrm{~m} / \mathrm{sec}$ in a concrete drain, with as little curvature as possible (ENV, 1976). Working to these fixed specifications, engineers were heavily relied upon to administer the boundary between the population and water through practices of division and incarceration, acting as agents of internal colonization.

\section{Concrete crisis: dengue, mosquitoes and the coming of community}

Containing water in a closed system of predetermined conduits obdurately established by state fiat would centralize administrative capacities in respect to surveillance, ownership and government. By homogenizing the dimensions of waterways through geometric canalization the flow of water could be regularized, thereby enabling efficient, calculable conveyance and hydrological measurements. Beginning in 1968, hydrometric stations, flood gauges, telemetric systems and CCTV technology would be gradually embedded within the canal system to facilitate policing of both stormwater and proximate passers-by (ENV, 1977). This technological striation of waterways also facilitated a generalized process of centralization in respect to water and land ownership. The WPCDA had legally designated water the exclusive property of PUB, effectively bringing the entire water cycle under the control of the state. An essential revenue stream was established 
through the sale of water to domestic and non-domestic customers, which could be charged and taxed with the introduction of individualized meters.

The governmental reach of the state was thereby extended into the everyday lives of the population as piped water entered homes and workplaces. An essential feature of the modern state, the quotidian conduct of citizens could henceforth be monitored and manipulated through the instalment of water meters, thimbles and flow regulators, enabling the subsequent introduction of pricing mechanisms, fiscal incentives and public education programmes. The widely maligned 'water waster' would be gradually reformed into a personally responsible, calculating subject, one that practices restraint and respect for scarce water resources under a general sense of obligation to the nation (ST, 1971). Engineers concretized and naturalized a new relationship of biopolitical dependency between the population, water and the state, predicated on infrastructural enclosure and centralized distribution (figure 1). Resettlement also released prime, increasingly state-owned land for development, which had formerly suffered from regular flooding or had been occupied by intractable, politically antagonistic slums and unproductive, small-scale industries, enhancing its administrative and fiscal capabilities.

However, security mechanisms came to supplant those of discipline in response to a generalized crisis of closed systems and monopoly control of water resources. A coordinated, technical process of decentralization would follow as successive pressures compelled the state to relinquish hierarchical control. Mosquitoes had taken refuge in the covered drainage system leading to outbreaks of dengue fever, whilst modern conveyance techniques had proven detrimental to anti-flood initiatives and biodiversity protection. Water quality was also jeopardized as the social and emotional bond between citizens and water had been physically severed thereby undermining the state's anti-littering agenda (Hansard, 1990). Furthermore, the developing service economy required waterfront land for recreational usage and property development (URA, 1989). Through mechanisms of security a more dispersed form of government would be facilitated by removing physical barriers and encouraging citizens to affectively interact with water through lifestyle and community initiatives:

There needs to be a strategy of engagement with the larger population so that they take responsibility to keep the catchment clean...Changing hard concrete, changing canals into rivers, changing reservoirs into lakes which people can enjoy. By enjoying that environmental asset, they'll get closer to water and hopefully build a relationship and therefore value water (interview/1). 
The crisis of mosquito control is particularly revealing of the enduring tension between security and discipline, where water circulation was made more accessible to a wider spectrum of the population. In the interests of preventing water pollution, the campaign to cover drains in Singapore's housing estates and litter-prone areas was accelerated in the 1990s. Drainage in public and private housing estates was covered, followed by popular areas located towards the city centre, completed in 1992 (ENV, 1992). However, the policy of covering drainage channels was linked with a rise in mosquito numbers and outbreaks of dengue in Singapore. Although the WHO had officially registered Singapore as a malaria-free country in 1982, the Aedes mosquito that serves as a vector for dengue thrives in mere millimetres of clean water rather than the marshy conditions that its malarial cousin prefers, the Anopheles. During the 1990s, instances of dengue significantly increased in Singapore and in other countries due to higher levels of urbanization, migration and tourism (Gandy, 2014). As part of the state's programme of source reduction, drains would become a key target of surveillance.

Town Councils were now facing the difficult decision as whether to continue with the long-term policy of closing drains to prevent litter or to remove covers to allow easier access for flushing clogged drains. Councils at risk of dengue outbreaks, reluctant players in an emerging politics of the milieu, were forced to consider a mass removal of concrete drain covers that had recently been laid at great public cost. The situation deteriorated steadily throughout the decade with no sign of abatement when in 1996 an outbreak occurred, resulting in 3,128 cases of dengue and four deaths (ENV, 1996). Town Councils began to remove drain covers wholesale to facilitate surveillance and flushing operations (ST, 1997). Minister for the Environment, Yeo Cheow Tong, was not exactly reticent about the uncertainties associated with their carrying out the government of circulatory coexistence: 'How does the measure to remove drains covers reconcile with the earlier measure, which is to ask that drains be covered up?' (Hansard, 1998).

A minimum gradient was stipulated for future drainage installations so that water would be less likely to accumulate, whilst a porous geotextile lining called 'Enkadrain ST' was introduced by state engineers to allow water to percolate through to a sub-soil layer. Drainage engineer Lim Meng Check acknowledged that lining drains with Enkadrain ST would cost $10 \%$ more than conventional methods but they would prevent mosquito breeding (ST, 1999). Concrete, reassuringly impermeable, terra firma epitomized, had proven to be too unyielding, too precise, too modern. Whereas cases would continue to rise the following two years after the 1996 outbreak- 4,300 in 1997 and 5,258 in 1998- they 
would drop to the more manageable level of 673 patients in 2000 (ENV, 2000). However, design features of housing that were conducive to water pooling - canopies, deck roofs, bamboo fittings and covered drains- persisted due to a lack of available funding for upgrading. Therefore when the next dengue outbreak occurred in September 2003, residents were drafted as part of the integrated approach requiring the removal of concrete covers. Grassroots organizations and volunteers from Residents' Committees were mobilized to distribute educational pamphlets door-to-door. By mid-October, the outbreak was under control. Whereas it would take state authorities operating autonomously three weeks to regain control, with grassroots involvement it was calculated the timescale could be reduced to just ten days (Hansard, 2004a).

When Singapore suffered its worst ever dengue epidemic in 2005, resulting in nineteen deaths, 4000 dengue prevention volunteers were primed for intervention along with community and grassroots groups. Under immense pressure, the Environment Minister refused to return to the manifestly disciplinary techniques that were being advocated by other MPs, such as 'sheltering, isolating and ring-fencing all these patients' in 'special isolation shelters' and 'self-quarantine' (Hansard, 2005). Neoliberal mechanisms of security were now standard operating procedure based on citizen participation and 'the information and the knowledge they need to combat dengue' themselves. A responsibilized brigade of community volunteers now made for rapid and flexible response, assisting by drilling holes in ashtrays, filling in tree holes with cement, land depressions with top soil, and detecting other places where water could collect. Community groups, schoolchildren and concerned citizens would earnestly and carefully scour these disreputable drains of disease and dirt for litter and mosquito larvae, whilst constantly checking their own conduct but also that of other volunteers. The removal of concrete drainage covers directly facilitated this process of administrative decentralization, which reflected a much profounder shift in governmental strategy.

Indeed, the milieu was undergoing a coordinated process of transformation in accordance with a series of urban planning and engineering objectives, where the material design and governmental efficacy of concrete became a matter of concern (Barry 2013). Source control techniques would provide the foundation for a decentralized, relational system of stormwater management (Karvonen, 2011). These were not merely aesthetic or environmental projects but strategic interventions in the urban milieu to reconfigure the administrative boundary between the population and water circulation. The methods and utopian horizon of government, what Dean (2010) refers to as techne and telos respectively, were officially revised in the Singapore Green Plan. Drawing on the proposals of the 
Waterbodies Design Panel, which was appointed in 1989 to revise existing guidelines for waterfront development, the plan proposed a more interactive role for water in the process of government (URA, 1993). The edge condition was a site of much calculation and deliberation for the panel; how the spatial continuum between the terrestrial and aquatic affects the ambience of a waterfront and 'determines the sort of relationship that can be established between the landscape and the water' (Ibid: 25). Whereas up until the mid1980s waterways had been developed as geometric, generally undesirable sluices for rainfall and oftentimes refuse, they would undergo a functional and aesthetic revolution. The panel recommended that state engineers should be accompanied by private landscape designers and architects, where materials such as stones, vegetation and water itself could be introduced to blur the sharp edges of concrete through natural contouring.

The objective was to shift attention from 'hardware' to subtler types of 'software' that would engage the public and make them 'feel for the environment' through participation and cultural interventions (ENV, 1993: 2). Disciplinary measures such as fines, surveillance and standards had been instrumental, but further improvement would be made by adopting an integrated approach that encouraged environmentalism as a 'lifestyle' choice, bringing citizens into affective contact with water and its infrastructure of circulation. Periodic and didactic, the former conservation message that water should not to be wasted or polluted was failing to linger in the public imagination, necessitating more continuous, ingrained methods of engagement at the community level (Hansard, 1986). Responsibility would be decentralized through urban design to third sector organizations, private companies, community groups and individual citizens, relieving pressure on the centralized state.

\section{Drainage, desire and the ABC Waters Programme}

In 1995 the Singapore Environment Council (SEC), a non-profit NGO, was established to orchestrate this transition, 'primarily set-up by the Government' to 'reach out [and] touch as many segments of society as possible' (interview/13). Acting as an umbrella organization for environmental groups operating in the embryonic third sector, the SEC would organize national-awareness campaigns and create eco-labelling certification schemes and other voluntary initiatives. Although the SEC is publicized as autonomous, it continues to receive monetary and interpersonal support from state agencies, which hold influence on board recruitment. Similarly, the Waterways Watch Society (WWS) was set up with $\mathrm{S} \$ 50,000$ of seed money from the Environment Ministry and has direct access to various 
state officials (interview/9). The WWS conducts educational programmes with schools and private companies during the week, although they are more renowned for their weekend reservoir patrols of Marina Bay and Kallang Basin (figure 2). Weekly reports including photos of litter hotspots and offenders are submitted to various state agencies and the police force, prompting enforcement action if required.

Evidently, the institutional boundary between the state and the third sector is purposefully blurred (interview/12). Approval ratings of the PAP have been steadily declining with the expected abatement in economic growth and advance of opposition parties such as the Workers Party, whilst diplomatic relations with Malaysia and Indonesia have become undeniably strained. As one high-ranking representative of SEC proclaimed, 'it's not going to be any use if people kind of think of us as another Government arm' (interview/13). Strategic ambiguity was the central impetus for the formation of WWS, which provides an ostensibly apolitical, elastic and socially-embedded network through which the art of government can be more delicately exercised: 'As I bring in more of these [volunteers], even when they're off duty, they know what to do, what's right and wrong. They know who to call if they spot something' (interview/9.). The strategically depoliticized and networked configuration of SEC enhances the penetrative capacity of the state, constituting a markedly more sophisticated, less confrontational form of government:

We are going to be able to get a mass of people at a snip of a finger, because we have got our networks. Whereas if the Government tries to get people behind them, I think right now, there will be resistance because of political changes (interview/13.).

These dispersed networks are not only institutional but infrastructural in composition, qualitatively extending the reach of government through the unbundling of material networks of circulation. On 9 October 2004, restrictions pertaining to reservoir spaces were relaxed by the water authority, significantly modifying water ownership relations (PUB, 2004). To protect this essential resource from contamination and exhaustion, water had been separated from the population over a number of decades by engineers through canalization. Patrol teams had stalked reservoir sites on speedboats and motorbikes, dressed in uniforms and equipped with retractable batons. It was also illegal for rainwater to be directly collected or taken from waterways and reservoirs because, as one politician starkly stated, 'water belongs to PUB' (Hansard, 2004b). However, from October 2003 households and developers would be able to collect rainwater in storage tanks for non-potable uses. 
Concurrently, recreational activities and water sports would be progressively introduced to selected reservoirs to glamorize and rebrand water as a luxury consumer good, whilst aligning environmental conduct with individual aspirations for fashionable and funseeking lifestyles. Public relations strategy at PUB was extensively reformed in 2005 to reflect this shift, which rebranded water as socially, and indeed, sexually desirable. Annual reports, pamphlets and magazines depicted reservoirs and rivers as spectacular backdrops for romantic picnics, extreme sports, celebrity interviews and modelling shoots of attractive models, 'making water hip' (PUB, 2008a: 42). PUB engineers underwent in-house training to become more entrepreneurial and were offered scholarships to specialize in environmental engineering, source control technology and systems-approach management (PUB, 2004). The scholarship programme would eventually be extended into 'non-engineering..."softer" skills' such as public communications, marketing and commercial development (PUB, 2012). Furthermore, to counter the prevailing image of 'engineers being "square'"' (PUB, 2005: 27), they began to regularly appear in 'lifestyle' features for PUB reports engaged in daring pursuits such as kayaking, skydiving and belly-dancing. The mobilization of desire, through the affective disposition of both engineers and water users, was becoming a central if implicit element of state policy.

A '3P Network' department was formed specifically oriented towards stakeholder engagement, which would be coordinated through the physical integration of water into terrestrial areas (PUB, 2004). The overarching policy objective of the 3P Department was to extend a sense of ownership over water resources to the population, to promote an emergent civil society and sense of 'active citizenship' (Hansard, 1997). Using MacRitchie and Bedok Reservoirs as platforms, the Active, Beautiful and Clean Waters (ABC) programme would be introduced in April 2006 to provide an 'umbrella' project for 3P initiatives, incorporating both 'software' and 'hardware'. Gabions, cribwalls, wetlands, swales, porous pavements and green roofs would naturalize waterways and adjacent areas whilst slowing, retaining and treating stormwater on site (PUB, 2009). Government would increasingly be exercised through contouring as opposed to concrete and implemented in a horizontal rather than vertical register, purposefully de-monopolizing the state's jurisdiction over the resource through 'stormwater decentralization' (Ibid: 10). Reminiscent of the drainage controversy which contemplated the complex coexistence of citizens and circulation, the Environment Minister rhetorically asked 'to keep our waters clean, do we keep people away, or do we bring them nearer?' (Hansard, 2009).

A sum of $\mathrm{S} \$ 200$ million was set aside for the development of 28 projects, which would occur in tandem with the private sector over the ensuing five years. In partnership 
with the 3P Department, PUB sought to 'tap ideas, expertise and resources' from the community as well as from business, imprinting in landscape this decentralized style of government (PUB, 2008b: 3). The first scheme to be completed was along a $200 \mathrm{~m}$ section of Kallang River at Kolam Ayer in 2008. A 'water wheel' was constructed that allowed residents to draw water from the Kallang River and play with it, 'making it a part of their everyday lives' (PUB, 2008b: 15). Further up the Kallang River from Kolam Ayer, the flagship ABC project was completed at Bishan-Ang Mo Kio Park in 2012 (PUB, 2012). This project transformed a large 2.7 kilometre section of concrete trapezoidal canal into a naturalized meandering waterway (figure 3). Cobble paths and stepping stones traverse the waterway to encourage visitors to negotiate the canal-cum-river, descending underwater and emerging on the opposite bank. Initially, there was resistance from some civil engineers due to the novel methods of stormwater management and inclusion of landscape professionals that had formerly critiqued traditional engineering solutions, advocating instead a 'behavioural framework of urban design' based on ecology and 'experiential' characteristics (CH2MHill/Atelier Dreiseitl, 2007: 5). On completion the consultant landscape architect Herbert Dreiseitl made the pointed remark that it is very much about emotions, not only statistics' (CUGE, 2012: 127).

However, as a staff member from the 3P Department affirmed, this still largely concerns questions of 'physical engineering' (interview/2). This is necessary but 3P initiatives are implemented in parallel with ABC projects: 'It's the hardware; we're the software...it's allowing people to get closer to water. But the glue, the thing that actually allows people to interact with the $A B C$ sites, is what we do. We aim for your head but actually we want your soul'. The principle method of engaging visitors would be through the Learning Trail programme, established in 2011 at selected $A B C$ sites and incorporated into the school curriculum. As part of a school fieldtrip or family visit, students are encouraged to explore reservoirs and learn about their history, biodiversity and unique characteristics, to assume joint ownership of Singapore's waterways (PUB, 2011). Rather than managing water as if it were 'pristine' or 'holy', PUB would increasingly use water as a technology of government (interview/2.). Where students are concerned, the strategy is to draw them towards the water through a seductive rather than coercive modality of power: 'What I wanted was something which would entice you, bring you in- you know it's like the Black Widow on her web- entice you to come in' (interview/2).

The 'web' being referred to here is networked together by strategically arranged material interventions into waterfront space. Comparably as important to this approach of government, which Foucault attempted to capture with his very specific choice of the word 
'conduct', is the circular and relational organization of its application. Hierarchy and docility are actively eschewed in favour of information dissemination. The long-term objective of the learning trails is to avoid overtly didactic interventions from state officials. Instead, an emerging civil society has been increasingly and authentically encouraged by PUB to assume responsibility for water resources. Children are now expected to conduct learning trails without the continued assistance of teachers or guides: 'They become the head honchos of the trail; they become the super divas of the trail. They lead other children on the trail' (Ibid).

In April 2012, SEC were appointed to publicize the learning trails programme and reach out to secondary school students after being awarded the tender (PUB, 2012). This arrangement is exemplary of the revised approach to government as state officials, NGOs and members of the public are all implicated in the process of disseminating, learning and administering, where responsibility is dispersed and circular. It was the decentralized networked capacity of SEC that persuaded PUB to select them as vendor: 'PUB needed to reach out to schools to get kids to visit these waterbodies and take ownership of the spaces around them...what we are able to give the Government is this ability to reach out' (interview/13). In addition to school contacts, SEC has links with other NGOs and social enterprises which can be drawn upon to circulate the water authority's objectives throughout civil society. According to one entrepreneur and voluntary facilitator, the $A B C$ learning trails are a principle vehicle for this new focus on volunteerism, through which organizations are able to freely contribute: 'By having free will, [PUB] just provide the guidelines. Anybody can contact ABC Trails...this is what the Government is doing, they are more like governors...at the end of the day, the people that finally do the trail are people who are interested' (interview/15).

The WWS were also invited by SEC to participate in the learning trails programme. WWS volunteers lead discussions on water conservation at reservoir sites, using landscaping features to decentralize responsibility to the local community. During an initial recruitment exercise, WWS persuaded local residents to become volunteers: 'They are going to be given the leadership with us supporting, and they are going to lead because it's their hometown, you see? Creating a community role for them but also working in line with our mission, keeping our waterways clean' (interview/13). Depoliticized, individualized and networked, the WWS affords state agencies an unrivalled opportunity to promote a neoliberal and lifestyle-oriented approach to government on the waterfront. The whims and wants of an emerging civil society would be actively unbridled, entailing a shift in telos towards individual aspiration and desire as opposed to collective docility and self-restraint. The next phase, 
according to a 3P representative, is to engage the population in the process of engineering itself: 'How are pipes dug? What is water quality like? How does it come to you?...This is getting people to come in to the spider's web first and then [makes eating noise]. Trying to get them into the bowels of the earth so they really understand the pipes' (interview/2).

\section{Engineering the milieu, reconfiguring the state}

This paper has argued that engineers, alongside landscape architects, decentralized responsibility and ownership of water to an emerging civil society through the infrastructural retrofitting of drainage. This was embedded within, and facilitative of, a wider governmental shift towards 'active citizenship' across all sectors of state policy. Not only were disciplinary methods challenging to implement but produced a diverse range of negative effects in terms of water quality, flooding, mosquito control, public relations, biodiversity and property development. This was a biopolitical crisis of closed systems and concrete modernism, and indeed, a crisis of government under the centralized state, which is a local expression of a much broader critique (Scott, 1998). Consequently, government would be increasingly exercised through technologies of exposure, facilitated by the calculated entry of water into everyday urban life. Where concrete had previously circumscribed waterways and drains to assert monopoly state ownership, naturalized landscapes would physically recalibrate the administrative boundary between the state and population under revised urban design guidelines and government legislation.

The techne and telos of government were reformed through these legislative and engineering measures, where responsibilized citizens are increasingly governed as active rather than docile subjects in dispersed, depoliticized networks oriented around desire as opposed to restraint. 'Nature' has been partially liberated from the stranglehold of the state, physically in terms of water and conceptually in regard to civil society, with both of these processes coming together in the milieu of the waterfront. Watersports, festivals and other leisure activities would become strategic vehicles for a modality of power oriented towards seduction rather than subordination, centrifugally unleashing the potency of water flows and human desire in what could be termed the 'libidinal economy' (Lyotard, 2004). Extensions of community-based drainage surveillance, the $\mathrm{ABC}$ programme and $3 \mathrm{P}$ Department are decidedly contemporary approaches to this neoliberal form of government, which seek to activate, individualize and empower citizens through affective engagement with water.

It can therefore be ventured that an alternative governmental regime was inaugurated through the intricate retrofitting of drainage conduits, elucidating the 
underexplored relations between 'ecology, epidemiology and infrastructure...the biopolitical dynamics of infrastructure networks' (Gandy, 2014, p.5). Networked urban infrastructure solidifies, normalizes and naturalizes social relations and citizen subjectivities, mediating the biopolitical relationship between the public and private realms, connecting the state, territory and population in complex, mutable assemblages (see Björkman, this issue). Whilst contemporary shifts in environmental governance are increasingly interpreted as sociotechnical in character, occurring at the intersection between governmental, political and infrastructural change (Hodson and Marvin, 2013; Bouzarovski et al, 2015), this paper has sought to demonstrate that such transitions not only realign resource use practices but ontologically restructure the material-ecological basis of the state (see Mitchell, 2011). Infrastructure has not only provided the urban matrix of the modern state but continues to facilitate its ongoing transformation through everyday maintenance, repair and retrofitting processes (Bulkeley et al, 2014). As Scoones et al (2015) have suggested, socio-technical transformations cannot be adequately understood without taking power relations into serious account.

Challenging the mainstream account of governmentality, which has invariably and narrowly focused on the biopolitics of the population, the analytical significance of the milieu and the related issue of engineering has been reiterated. As Philo (2012) has proposed, we are being presented with a 'new Foucault' oriented towards the lively, affectual and 'Dionysian' characteristics of biopolitical existence rather than static grids of disciplinary coercion, suggesting a liquid vitality that both challenges and augments governmental capacities (Anderson, 2012). And indeed, the contemporary transition to IWRM appears to be occurring precisely at the point of intersection between matters of state and states of matter, necessitating further research on hydraulic engineering and the material efficacy of water for government (Bear and Bull, 2011). Critical attention should turn to how government is increasingly exercised through the engineering of permeable boundaries, ecological linkages and landscaped open systems (De Block, 2016), where flux does not only set the limits to statecraft but provides a strategic medium of intervention. 


\section{References}

Amin, A. (2014) Lively infrastructure. Theory, Culture \& Society 31.7/8, 137-161.

Anderson, B. (2012) Affect and biopower: towards a politics of life. Transactions of the Institute of British Geographers 37.1, 28-43.

Bakker, K. (2010) Privatizing water: governance failure and the world's urban water crisis. Ithaca NY, Cornell University Press.

Barry, A. (2001) Political machines: governing a technological society. London, Athlone Press.

Barry, A. (2013) Material politics: disputes along the pipeline. Oxford, Wiley-Blackwell.

Bear, C. and Bull, J. (2011) Water matters: agency, flows, and frictions. Environment and Planning A 43.10, 2261-2266.

Bennett, T. and Joyce, P. (ed.) (2010) Material powers: cultural studies, history and the material turn. London, Routledge.

Björkman, L. (2015) Pipe politics, contested water: embedded infrastructures of millennial Mumbai. Durham, NC: Duke University Press.

Bouzarovski, S., M. Bradshaw and A. Wochnik (2015) Making territory through infrastructure: the governance of natural gas transit in Europe. Geoforum 64, 217-228.

Brenner, N., J. Peck and N. Theodore (2010) Variegated neoliberalization: geographies, modalities, pathways. Global Networks 10.2, 182-222.

Bridge, G. (2013) Territory, now in 3D! Political Geography 34, 55 - 57.

Brott, S. (2012) Collective equipments of power: the road and the city. Thresholds 40, 47 54.

Bulkeley, H., V. Castán Broto and A. Maassen (2014) Low carbon transitions and the reconfiguration of urban infrastructure. Urban Studies 51.7, 1471-1486.

Camprubí, L. (2014) Engineers and the making of the Francoist regime. Cambridge, MA, MIT Press.

Carroll, P. (2012) Water and technoscientific state formation in California. Social Studies of 
Science 42.4, 489-516.

Centre for Urban Greenery and Ecology [CUGE] (2012) Citygreen issue 5. Singapore, CUGE.

CH2MHill/Atelier Dreiseitl. (2007) ABC Waters Master Plan for the central catchment. Singapore, CH2MHill/Atelier Dreiseitl.

Chua, B. H. (2011) Singapore as model: planning innovations, knowledge experts. In A. Roy and A. Ong (Ed.), Worlding cities: Asian experiments and the art of being global, Oxford, Blackwell.

Collier, S. J. (2011) Post-Soviet social: neoliberalism, social modernity, biopolitics. Princeton, NJ, Princeton University Press.

Collier, S. J. and Lakoff, A. (2015) Vital systems security: reflexive biopolitics and the government of emergency. Theory, Culture \& Society 32.2, $19-51$.

De Block, G. (2016) Ecological infrastructure in a critical-historical perspective: from engineering 'social' territory to encoding 'natural' topography. Environment and Planning $A$ 48.2, 367-390.

Dean, M. (2010) Governmentality: power and rule in modern society. London, Sage.

Elden, S. (2013) Secure the volume: vertical geopolitics and the depth of power. Political Geography 34, 35-51.

Elden, S. (2016) Foucault's last decade. Cambridge, Polity.

Forty, A. (2012) Concrete and culture: a material history. London, Reaktion Books.

Foucault, M. (1980) The eye of power. In C. Gordon (Ed.), Power/knowledge: selected interviews and other writings 1972-1977, New York, Pantheon Books.

Foucault, M. (1989a) Space, knowledge and power. In S. Lotringer (Ed.), Foucault live: collected interviews, 1961-1984, New York, Semiotext(e).

Foucault, M. (1989b) Equipments of power. In S. Lotringer (Ed.), Foucault live: collected interviews, 1961-1984, New York, Semiotext(e).

Foucault, M. (2003) Society must be defended. New York, NY, Picador.

Foucault, M. (2007) Security, territory, population. Basingstoke, Palgrave Macmillan. 
Foucault, M. (2008) The birth of biopolitics. Basingstoke, Palgrave Macmillan.

Gabrys, J. (2014) Programming environments: environmentality and citizen sensing in the smart city. Environment and Planning D: Society and Space 32, 30 - 48.

Gandy, M. (2002) Concrete and clay: reworking nature in New York City. Cambridge, MA, MIT Press.

Gandy, M. (2014) The fabric of space: water, modernity, and the urban imagination. Cambridge, MA, MIT Press.

Graham, S. and Marvin, S. (2001) Splintering urbanism. London, Routledge.

Graham, S. and Thrift, N. (2007) Out of order: understanding repair and maintenance. Theory, Culture \& Society 24.3, 1- 25.

Guldi, J. (2012) Roads to power: Britain invents the infrastructure state. Cambridge, MA, Harvard University Press.

Hansard (1961) Development Plan 1961-1964. Session 2, vol. 14.

Hansard (1958) Flood prevention. Session 3, vol. 7.

Hansard (1971) Debate on President's Address. Session 2, vol.3.

Hansard (1975) Water Pollution Control and Drainage Bill. Session 2, vol.34.

Hansard (1986) Water supply. Session 2, vol. 48.

Hansard (1990) Budget, Ministry of the Environment. Session 1, vol. 55.

Hansard (1997) Community Service of Students. Session 1, vol. 69.

Hansard (1998) Budget, Ministry of the Environment. Session 1, vol. 68.

Hansard (2004a) Dengue outbreak in Braddell Heights Estate. Session 1, vol. 77.

Hansard (2004b) Head L- Ministry of the Environment. Session 1, vol. 77.

Hansard (2005) Dengue control measures. Session 2, vol. 80.

Hansard (2009) Head L- Ministry of the Environment and Water Resources. Session 1, vol. 85. 
Haque, M. S. (2004) Governance and bureaucracy in Singapore: contemporary reforms and implications. International Political Science Review 25.2, 227-240.

Harris, A. (2013) Concrete geographies: assembling global Mumbai through transport infrastructure. City 17.3, $343-360$.

Harvey, P. (2010) Cementing relations: the materiality of roads and public spaces in provincial Peru. Social Analysis 54.2, 28 - 46.

Harvey, P. and Knox, H. (2012) The enchantments of infrastructure. Mobilities 7.4, 521 536.

Hodson, M. and Marvin, S. (2013) Low carbon nation? Abingdon, Routledge.

Jones, P. and Macdonald, N. (2011) Making space for unruly water: Sustainable Drainage Systems and the disciplining of surface runoff. Geoforum, 38, $534-544$.

Joyce, P. (2003) The rule of freedom: liberalism and the modern city. London, Verso.

Joyce, P. (2013) The state of freedom: a social history of the British state since 1800. Cambridge, Cambridge University Press.

Kaika, M. (2005) City of flows: modernity, nature, and the city. London, Routledge

Kaika, M. (2006) Dams as symbols of modernization: the urbanization of nature between geographical imagination and materiality. Annals of the Association of American Geographers 96.2, 276-301.

Kaika, M. and Swyngedouw, E. (2000) Fetishizing the modern city: the phantasmagoria of urban technological networks. International Journal of Urban and Regional Research 24.1, 120-138.

Karvonen, A. (2011) Politics of urban runoff: nature, technology, and the sustainable city. Cambridge, MA, MIT Press.

Lemke, T. (2015) New materialisms: Foucault and the 'government of things'. Theory, Culture \& Society $32.4,3-25$.

Linton, J. and Budds, J. (2014) The hydrosocial cycle: defining and mobilizing a relationaldialectical approach to water. Geoforum 57, 170 - 180.

Lyotard, J. (2004) Libidinal economy. London, Continuum. 
Mauzy, D. and Milne, R. (2002) Singapore politics under the People's Action Party. London, Routledge.

McFarlane, C. and Rutherford, J. (2008) Political infrastructures: governing and experiencing the fabric of the city. International Journal of Urban and Regional Research 32.2, 363-374.

Miller, P. and Rose, N. (2008) Governing the present. Cambridge, Polity Press.

Ministry of the Environment [ENV] (1972) Annual Report. Singapore, ENV.

ENV (1975) Annual report. Singapore, ENV.

ENV (1976) Code of practice on surface water drainage. Singapore, ENV.

ENV (1977) Annual report. Singapore, ENV.

ENV (1990) Tidal fortunes: a story of change: the Singapore River and Kallang Basin. Singapore, Landmark Books

ENV (1992) Annual report. Singapore, ENV.

ENV (1993) ENVNews. No.27. Singapore General Printing.

ENV (1996) Annual report. Singapore, ENV.

ENV (2000) Annual report. Singapore, ENV

Minuchin, L. (2013) Material politics: concrete imaginations and the architectural definition of urban life in Le Corbusier's Master Plan for Buenos Aires. International Journal of Urban and Regional Research 37.1, 238 - 258.

Mitchell, T. (2002) Rule of experts: Egypt, techno-politics, modernity. Berkeley, CA, University of California Press.

Mitchell, T. (2011) Carbon democracy: political power in the age of oil. London, Verso.

Monstadt, J. (2009) Conceptualizing the political ecology of urban infrastructures: insights from technology and urban studies. Environment and Planning A 41.8, 1924-1942.

Mukerji, C. (2003) Intelligent uses of engineering and the legitimacy of state power. Technology and Culture 44.4, 655-676. 
Mukerji, C. (2009) Impossible engineering: technology and territoriality on the Canal Du Midi. Princeton, NJ, Princeton University Press.

National Archives of Singapore [NAS] (1970) File no. PWD 223/53, Vol.5.

NAS (2007) Tan Gee Paw interview: the civil service- a retrospection (interviewer Dr Jason Lim) file no. 003170/6.

NAS (2012a) The papers of Lee Kuan Yew: speeches, interviews and dialogues, volume 5, 1969-1971, Singapore, Seng Lee Press.

Neo, H. (2007) Challenging the developmental state: nature conservation in Singapore. Asia Pacific Viewpoint 48.2, 186-199.

O' Grady, N. (2013) Adopting the position of error: space and speculation in the exploratory significance of milieu formulations. Environment and Planning D: Society and Space 31.2, $245-258$.

Ong, A. (2007) Neoliberalism as a mobile technology. Transactions of the Institute of British Geographers 32.1, 3-8.

Philo, C. (2012) A 'New Foucault' with lively implications; or 'the crawfish advances sideways'. Transactions of the Institute of British Geographers 37.4, 496-514.

Pow, C. P. (2014) License to travel. City 18.3, 287 - 306.

Pritchard, S. B. (2011) Confluence: the nature of technology and the remaking of the Rhône. Cambridge, MA, Harvard University Press.

Public Utilities Board [PUB] (2004) Annual report. Singapore, PUB.

PUB (2005) Annual Report. Singapore, PUB.

PUB (2008a) Annual Report. Singapore, PUB.

PUB (2008b) ABC Waters Masterplan. Singapore, PUB.

PUB (2009) Active, Beautiful, Clean Waters: design guidelines. Singapore, PUB.

PUB (2011) Annual report 2010/2011. Singapore, PUB.

PUB (2012) Annual report 2011/2012. Singapore, PUB. 
Sage, D., P. Fussey and A. Dainty (2015) Securing and scaling resilient futures: neoliberalization, infrastructure, and topologies of power. Environment and Planning D: Society and Space 33.3, $494-511$.

Scoones, I., M. Leach, and P. Newell. (ed.) (2015) The politics of green transformations. London, Routledge.

Scott, J. C. (1998) Seeing like a state: how certain schemes to improve the human condition have failed. New Haven, CT, Yale University Press.

Shatkin, G. (2014) Reinterpreting the meaning of the 'Singapore model': state capitalism and urban planning. International Journal of Urban and Regional Research 38.1, 116-137.

Straits Times [ST] (1951) 18 May 'Big drainage problem, but no workers'.

ST (1971) 29 May 'Saving water'.

ST (1997) 8 August 'Town councils remove drains' cement covers'.

ST (1999) 20 September 'Lining to keep drains dry'.

Swyngedouw, E. (2004) Social power and the urbanization of water: flows of power. Oxford, Oxford University Press.

Swyngedouw, E. (2015) Liquid power: contested hydro-modernities in twentieth-century Spain. Cambridge, MA, MIT Press.

Teo, S. (2014) Political tool or quality experience? Urban livability and the Singaporean state's global city aspirations. Urban Geography 35.6, 916-937.

Urban Redevelopment Authority [URA] (1989) Master plan for the urban waterfronts at Marina Bay and Kallang Basin (draft). Singapore, URA.

URA (1993) Aesthetic treatment of waterbodies in Singapore. Singapore, URA.

Usher, M. (2014) Veins of concrete, cities of flow: reasserting the centrality of circulation in Foucault's analytics of government. Mobilities 9.4, $550-569$.

Wakefield, S. and Braun, B. (2014) Governing the resilient city. Environment and Planning D: Society and Space 32.1, $4-11$.

Waley, P. and Åberg, E. (2011) Finding space for flowing water in Japan's densely populated 
landscapes. Environment and Planning A 43, 2321 - 2336.

White, B., W. Barry and Partners (1950) Report on the water resources of Singapore Island. London.

Worster, D. (1985) Rivers of empire: water, aridity, and the growth of the American West. Oxford, Oxford University Press.

Yeung, H. (2000) State intervention and neoliberalism in the globalizing world economy: lessons from Singapore's regionalization programme. The Pacific Review 13.1, 133-162.

[1] I would like to thank Stuart Elden for recommending the interview with Foucault on 'collective equipment'.

Figure 1 A typical example of trapezoidal canalization at Sungei [river] Pandan, complete with protective railings and adjacent corridors. During storm periods the canal transforms into a flowing stream that conveys rainwater to Pandan Reservoir. Photo by the author (2012).

Figure 2 A weekend patrol of Marina Reservoir conducted by WWS volunteers. Photo by the author (2012).

Figure 3 A naturalized section of Kallang River that was formerly a concrete 
trapezoidal canal. Stepping stones and cobbled pathways invite visitors to affectively engage with water. Photo by the author (2012). 